This article was downloaded by: [b-on: Biblioteca do conhecimento online IPP] On: 10 September 2012, At: 06:04

Publisher: Routledge

Informa Ltd Registered in England and Wales Registered Number: 1072954 Registered office: Mortimer House, 37-41 Mortimer Street, London W1T 3J H, UK

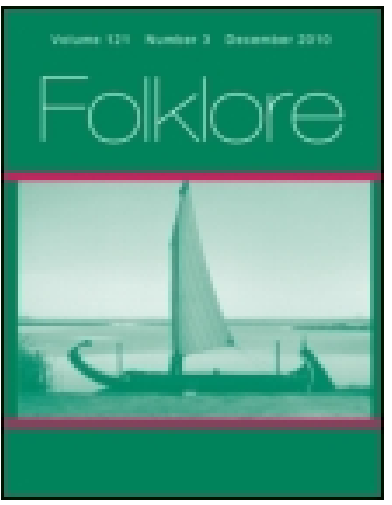

\title{
Folklore
}

Publication details, including instructions for authors and subscription information:

http:// www.tandfonline.com/loi/rfol20

\section{"All the World in a Boat": Portuguese Folklore, Common Sense and Ideology}

\author{
Clara Sarmento
}

Version of record first published: 14 Dec 2010.

To cite this article: Clara Sarmento (2010): "All the World in a Boat": Portuguese Folklore, Common Sense and Ideology, Folklore, 121:3, 268-291

To link to this article: http:// dx. doi.org/ 10.1080/0015587X.2010.511447

\section{PLEASE SCROLL DOWN FOR ARTICLE}

Full terms and conditions of use: http://www.tandfonline.com/page/terms-and-conditions

This article may be used for research, teaching, and private study purposes. Any substantial or systematic reproduction, redistribution, reselling, loan, sub-licensing, systematic supply, or distribution in any form to anyone is expressly forbidden.

The publisher does not give any warranty express or implied or make any representation that the contents will be complete or accurate or up to date. The accuracy of any instructions, formulae, and drug doses should be independently verified with primary sources. The publisher shall not be liable for any loss, actions, claims, proceedings, demand, or costs or damages whatsoever or howsoever caused arising directly or indirectly in connection with or arising out of the use of this material. 


\title{
"All the World in a Boat": Portuguese Folklore, Common Sense and Ideology
}

\author{
Clara Sarmento
}

\begin{abstract}
This essay sees "through" an object produced by Portuguese folklore: the moliceiro boat of Ria de Aveiro, whose most original characteristic is the group of four different panels painted on each boat. These unique panels have echoed national mythologies and have undergone influence from institutional channels of instruction and propaganda for much of the twentieth century. We will analyse how this boat expresses the inventory of a community's identity, imagination, and practices.
\end{abstract}

\section{Introducing a Portuguese Boat: Environment, Practices and Methodologies}

The moliceiro boat works within the Ria de Aveiro, the large lagoon-estuary of the River Vouga on the west coast of Portugal. [1] Located on the Western Atlantic coast of Portugal, between Espinho and Cape Mondego-or in broader terms, in a geographical area to the South of Oporto and North of Coimbra-the area covered by the lagoon corresponds approximately to a minimum of sixty-six square kilometres, at low spring tides, and a maximum of eighty-three square kilometres, at high spring tides. It is thus the most extensive shallow coastal lagoon in the country. There is an extensive and, nowadays, a densely-populated sand barrier along the coast-protecting and separating the enclosed lagoon from the Atlantic Ocean-where seasonal tourism, cattle breeding and agriculture coexist side by side.

Built of pine, the boat is flat-bottomed, wide across the beam, with very low sides, a shallow draught, and an unmistakable, extremely curved bow that reminds one of a half-moon or a bird's beak. The stern is also slightly curved. Traditionally propelled by a trapezium-shaped canvas sail, a pole or track rope, outboard engines are not uncommon additions nowadays. The first documented references to the moliceiro date to the first half of the eighteenth century, but this does not mean that moliceiros did not exist before that time, only that such a local popular artefact and related practices were not considered to be deserving of the attention of political and religious (that is, literate) authorities in earlier times.

The moliceiro boat was traditionally designed for gathering and transporting the seaweed, or moliço, growing in the Ria de Aveiro, in order to fertilise the surrounding sandy soils of the very small family farms on which largely unmechanised, subsistence-type agriculture was carried out. Moliceiros were also occasionally used to carry people, goods, and cattle, across the water. But one must always bear in mind that these boats, above all, are and were originally designed for the kind of agriculture practised in a particular amphibious ecosystem-the 
lagoon-that is both sea and river, land and water. Moliceiros are agricultural tools, just like an ox-cart or a plough.

The term moliceiro is also applied traditionally to those who worked aboard the craft: the boat owner, and/or one or two paid employees (camaradas), and/or an apprentice (moço), operating under a rather loose form of hierarchy. The boat owner could be a farmer collecting seaweed for his own land, or a professional wholesaler of moliço. Essentially, however, we are talking about a community of poor peasants who had to supplement their income with occasional fishing in the Ria, micro-scale agriculture, and some cattle breeding, among other kinds of shortterm or seasonal occupations. Most proprietors owned just one moliceiro, which usually changed hands many times during the two decades of the boat's average life expectancy. There were, however, exceptions such as the moderately wealthy landowners, who could afford to hold on to the craft indefinitely, or even to own up to ten moliceiros, operated by paid employees. Those who worked aboard the moliceiros did so in circumstances of extreme poverty. It comes as no surprise, therefore, that the massive emigration from the area which occurred in the 1960s and 1970s took most of the region's boat-hands and sounded the death-knell of the traditional industry of the moliceiro.

The purpose of the moliceiro has changed considerably in the past few decades. The former invaluable object of an entire region's economy has become a mere tourist attraction, a symbol whose preservation depends on each owner's goodwill and financial circumstances. Pollution, economic evolution and emigration have driven many people away from this unique way of life, chemical fertilisers have replaced the seaweed formerly used to fertilise the sandy soils, the salt industry has plummeted, and the roads have stolen the moliceiro's role as the main means of transport for the riverside population. While a thousand moliceiros were registered with the Aveiro Port Authority in 1935, nowadays, there are less than forty such registrations. Boat-building almost ceased due to the high emigration of the late 1960s and 1970s, but since the mid-1980s moliceiros have been revived as cultural assets. With increasing frequency, local mayors and local authorities are ordering new moliceiros from the surviving artisans, [2] to be used for tourism and guided tours of the Ria, for local museums or international

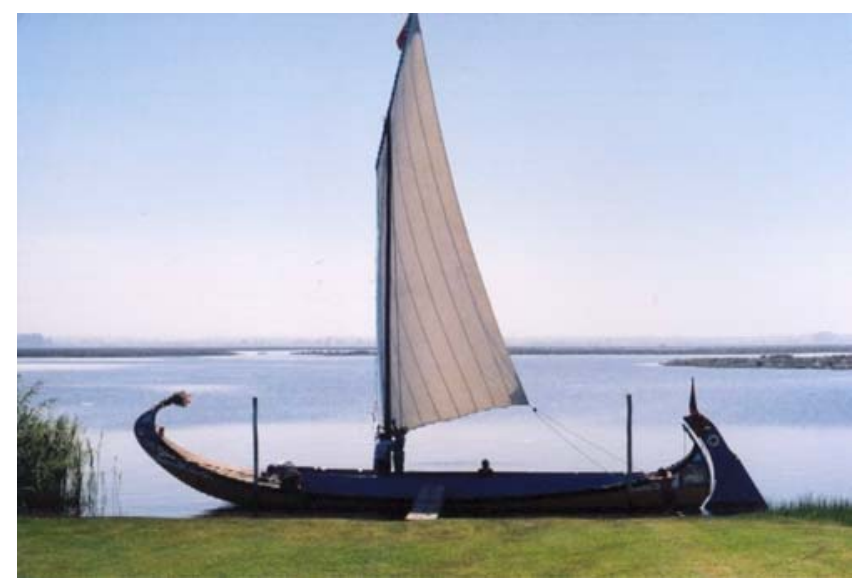

Figure 1. Moliceiro boat in Ria de Aveiro (2004). Photograph: Clara Sarmento. 
exhibitions, and for public display in a nearby canal in order to exemplify cultural heritage. Private companies also operate sightseeing tours aboard moliceiros. The tradition of the moliceiro is not doomed to disappear because of the fact that the boat was adapted to a new social and economic reality, thus assuring its survival and eventual increase in numbers. Conversely, had the moliceiros and boat owners insisted on working only in a type of rural environment that no longer exists, the boat would have been sentenced to an inevitable death (Figure 1).

The most original characteristic of the moliceiros is the set of four different panels that adorn the bow and the stern, all of which are covered with distinctive paintings in bright colours (blue, yellow, green, red, black, white), and captioned with a handwritten phrase. The bow panels follow the curve of the beak, whilst the stern panels are almost rectangular in shape. Both sets of panels have a bright border of several coloured strips of flowers and geometric figures. There is a multitude of subjects depicted on the panels of a moliceiro, in styles that range from the crudest drawings to exquisitely painted images. The artist, who might also be the boat-builder or a reputed amateur hired for the task, chooses the subject spontaneously or as suggested by the boat owner. In the latter case, the owner proposes a subject or theme, which the artist then illustrates according to his talent and imagination. An examination of more than five hundred panels recorded during regular periods of field work between 1988 and 2004 confirmed the existence of five main groups of panel images and inscriptions, and several subcategories: comic (satirising sex, work, institutions and famous characters); religious (celebrating Christ, the Virgin and the saints); social (depicting work situations-gathering seaweed, fishing, farming and ship-building-and ecological problems; celebrating nature, popular culture and local festivals, or illustrating common sayings and words of wisdom); historical (images of kings and queens, knights and soldiers, writers, and navigators); and entertainment (referring to folktales, television, the cinema, and football) (Figure 2).

Scattered and isolated communities, such as those that produced the moliceiro, usually develop their own codes, myths, heroes and social patterns. In the present case, these communities created a distinctive cultural object that simultaneously uses pictorial and linguistic codes, and coexistent semiotic systems that create a

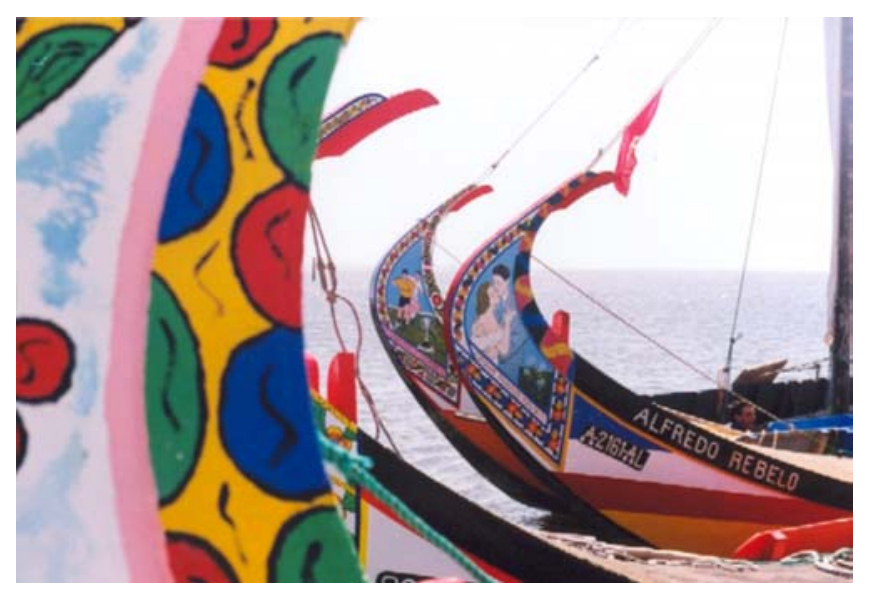

Figure 2. Panels of Moliceiros (late 1990s). Photograph: Clara Sarmento. 
phenomenon without parallel in Portuguese culture. This phenomenon symbolises both confrontation and compromise between the community and the outside world. In the present case, "a people who paint their boats and launch them into the waters of a lagoon, create an album of images through which they express their vision of the world" (Rivals 1988, 254).

The first stage of data collection for this research project consisted of participative field work undertaken in the Ria de Aveiro between 1988 and 2004, Photographs of the boats were assembled and interviews were carried out with surviving local boat-builders and painters, and with former employees of the traditional moliceiro craft-building industry. Images of the boats, and the way of life that surrounded them prior to the 1980s, were sourced from national and local (public and private) collections and museums. The next stage was to carry out research on the boats in local and national museums, archives, newspapers, parishes, municipalities, and any other relevant institutions. The special focus of this research was on iconography, tourism-oriented documentation, maps, local news and regulations, school textbooks, and popular literature. The Register of Boats, a handwritten collection of books in the archives of the Aveiro Port Authority, covering almost the whole of the twentieth century (between 1914 and 1998), was of special significance for the project, as was the official correspondence between the different local and central powers, during the period from the 1940s to 1974, preserved in the Historical and Municipal Archives of Aveiro. In addition, the various published works from the late nineteenth century onwards, dealing with the moliceiro and the Ria de Aveiro, were also critically evaluated.

\section{Historical and Ideological Constraints of Portuguese Folklore}

Between May 1933 and April 1974, Portugal was subjected to an authoritarian regime known as the Estado Novo, which was inspired by fascist ideologies and headed by António de Oliveira Salazar (1889-1970). This regime replaced the disordered sequence of governments of the post-October 1910 first Republic and a brief military dictatorship between 1926 and 1933.

Officially neutral during World War II, despite his obvious fascist sympathies, Salazar's main concerns during the following decades were the anachronic safeguarding of Portuguese colonies (which led to a tragic colonial war between 1961 and 1974) and the neutralisation of any kind of opposition at home. Salazar's efforts to organise the Nation in spatial, ideological and social terms, became evident at three different but complementary moments. These involved laudatory description of metropolitan and overseas provinces, and their vague, artificial but distinctive characteristics; generalisation of the beliefs and behaviour of the vague character called "the people"; and strict distribution, division and hierarchialisation of social roles. Nothing was left to the social actor's choice as everything was pre-determined and, according to the official discourse, accepted with assumed happiness, a spirit of self-sacrifice and noble resignation.

Authoritarian ideologies tend to be simplified in order to portray clear, unquestionable principles that present the right to command as something natural and legitimate, and the wish to resist as something futile and useless. According to authoritarian principles, the duty to obey is as simple and as inevitable as a natural phenomenon; hence, the real value of an ideologically-oriented political 
discourse lies in its disciplinary function, much more than in its specific precepts. Such was the case with Salazar's paradigmatic speech during the 28 May 1936 celebrations of the tenth anniversary of the National Revolution (the military dictatorship established in 1926), in which he identified the "unquestionable truths" of his new order:

To the souls that have been shattered by the doubts and negativism of this century, we return the comfort of great truths. We do not question God and virtue; we do not question Country and History; we do not question Authority and its prestige; we do not question Family and morals; we do not question the glory and duty of Work (Mattoso 1994, 291-4; my translation).

Thus "God," "Country," "Authority," "Family," "Work"—old ideological principles from fascist discourse-became the sacred principles of the Portuguese Estado Novo.

Despite the fact that ideology can present itself as a set of coherent ideas, it more frequently appears as a disparate collection of common-sense meanings, in a variety of forms and representations. Accordingly, it is worth undertaking a specific study of the forms of cultural organisation that keep the ideological world moving within a given country, and it is also worth examining how these actually function in practice. Popular culture texts and practices move within that which Gramsci calls a balance of compromise between power and consent; that is to say, within hegemony. All hegemonic relations are necessarily educational and occur in the several groups that constitute a society. The State demands consent but it also educates towards this consent. It is the great educator whose object is, at least according to its institutional discourse, to create a higher civilisation, and to mould the culture and morals of the popular masses to the nation's need for continuous development. The State, according to Gramsci, is the entire complex of practices and theoretical activities that the dominant classes use, not only to justify and keep their power but also to gain the consent of, and exercise hegemony over, subaltern classes (Gramsci 1971).

Therefore, dominated groups have to be persuaded that their condition, hopes and difficulties are unchangeable and inevitable. Convinced that nothing can possibly be done to improve their situation and that it will always remain so, criticism and aspirations will be eventually extinguished. As Pierre Bourdieu puts it: "Every established order tends to produce (to very different degrees and with very different means) the naturalisation of its own arbitrariness" $(1977,164)$. In a nation that desires to regenerate and educate the spirit of the age according to those unquestionable truths, ideologically-oriented teaching, both imposing, formative and repressive, is-as we will see-a sacred duty for every teacher in the public system, a system that is strategically purged of all unwanted subversive elements.

During the long years of dictatorship, Portuguese culture and traditions, either genuine, ideologically directed by the Estado Novo, or even invented, were used in order to instil into the people certain values and norms of behaviour, through repetition, example, and instruction, as a means of facing the threat of a world in evolution. These practices exploited an artificial, but a very effective, ideological basis by selecting a convenient historical past or ethnographic present. Traditional popular culture, in its ideal "folkloric" form, was seen as a perfect medium by the Estado Novo for reorganising society. The outcome of this work of domestication, 
called "folklore," was extremely useful for the Estado Novo's ideological strategy. As a result, it was able to combat the dangers of liberal, working-class and urban ways, with a model of rural celebration that reduced the concept of "people" to "peasant," with farmers, fishermen or craftsmen as the main social actors. This strategy of reduction was carried out with the willing assistance of those ethnographers who were close to the regime, and who, in the 1930s and 1940s, exalted the idea of primitivism, illiteracy, miserable humility and animal-like docility, as the ideal characteristics of the "good Portuguese people" (Silva 1994, 112).

The idea of "pure popular art" that portrayed everyday life from the naive, noncritical viewpoint of nineteenth-century ethnographers, matched the Salazar regime's ideal of a nation rich in folklore and picturesque custom. This was seen as a self-celebrating form of popular art, created by "good people" - mostly deeply religious peasants or fishermen who led austere, humble lives. The exaltation of handicraft, traditional costume, and rudimentary means of transport, reflected a way of life very similar to the subsistence living that the regime actually afforded Portuguese villages.

During the period of the Estado Novo, popular art forms, such as the moliceiro panels, also echoed official mythology as a more or less direct consequence of the influence of institutional channels of education and propaganda. Ideologically oriented stereotypes, forming part of collective memory, were appropriated and reproduced by people who adapted them according to their life experience and common sense. With regard to moliceiro culture, control by the State was implemented both directly and indirectly-directly through supervision, regulation, censorship, manipulation, and propaganda, especially by the local representatives of central power, and indirectly through the influence of Statecontrolled primary (that is, universal and compulsory) education and ideology.

Between 1957 and 1964 — some of the most repressive years of the regime-even the moliceiro panels, in addition to the boat, had to be registered (with a transcription and description of both sentences and images) at the local Port Authority. This was a form of direct State control, and it was also carried out in order to avoid subversive messages or shocking images, in moral and political terms. This shows how every vehicle of communication and creativity, including popular art, was subject to political supervision and/or to the Censura ("Official Censorship"), an institution that prevailed during the Second Republic, and lasted without interruption for almost fifty years (between May 1926 and April 1974).

As the colourful moliceiros are excellent symbols for local folklore, they have inspired a series of politically-oriented events where popular culture becomes "cultural entertainment" to be consumed by an external, non-local public. Moliceiros have always participated in local religious-secular popular festivals (romarias). At first they were simply a means of transport, but in the 1950s their role began to change. In the course of the twentieth century, local press reports of popular festivals became a reflection of ideological, political and social (r)evolutions. During the initial decades of the century, and continuing under the influence of the Romantics, there was a genuine fascination with the "beauty and purity" of popular culture. With the founding of the Republic in 1910, and during the period of political instability that followed, rival local factions appeared to take possession of popular festivals, and to use them as political weapons, accusing each other of bad planning, management, 
and propaganda, in bitter sensationalist articles. Later, when the Estado Novo began to reorganise (that is, to "normalise") the nation, local powers also manipulated local festivals, which became artificial celebrations of so-called "folklore." After a moralising clean-up that essentially extinguished all vestiges of ancient pagan practices, [3] Catholic authorities took strict control over the religious aspect of these events. Consequently, press articles criticised the so-called "immoral pagan practices," and emphasised the ever-growing elitism of these highly-civilised and orderly "modern" festivals, which attracted tourists and middle-class visitors from all over the country. Their original actors and owners, the local people, became secondary characters who acted for the pleasure of outsiders and foreign visitors.

In March 1954, the Ria de Aveiro hosted the first Moliceiro Panel Competitioncreated, supervised and judged exclusively by local representatives of political power-in which the three most "typically" decorated boats (meaning, in effect, that they were painted with colourful scenes of rural bliss and included harmless misspelled sentences) received much official attention and propaganda, but only a modest monetary reward. According to Gramsci, this strategy of rewarding individual or group activities considered by higher authorities to be worthy of praise and distinction, must be integrated into the "civilising" actions of the State, a strategy that is always immediately published in the official media.

The fact of indirect State control of moliceiro culture by the Estado Novo, by means of education and school-oriented ideology, requires some contextualisation. The Republic of 1910 tried, with limited success, to dignify primary education and its agents, whereas the Estado Novo successfully managed to reduce the significance of primary education. The requirement to engage in compulsory education was even reduced by the Estado Novo from four to three years, a situation that prevailed until the early 1960s. Primary teachers (mostly underpaid young women) were used as vehicles for political and religious indoctrination. Instead of promoting the primary school's educational role, the Estado Novo valued instead its ideological and disciplinary functions. School had become a tool in the hands of the State, to be used to teach virtues rather than professional practices or useful knowledge. Hanging a crucifix on the wall above the teacher's chair was compulsory in primary schools. In the school choir, students raised their voices in praise of the glory of Portugal, the dignity of work, and their love for the fatherland. Particular importance was afforded to teaching the students about the overseas Portuguese colonies, as the State felt that, by impressing on everyone the exact notion of the value of the overseas empire, the entire nation would adopt a colonial outlook.

The official national textbook consisted of a single volume, one for each year, containing texts for reading, a section on mathematics, and a long section on Catholic doctrine-actually, several of the reading selections consisted of prayers or devotional texts. The textbook for the fourth grade was slightly different in format from the other three, but similarly oriented in ideological terms, with a stronger political message replacing elementary religious doctrine. These textbooks, inspired by Italian school manuals from the Mussolini period, were strongly focused towards creating a collective nationalistic and Catholic mentality. Published under close government supervision by the Ministry of Education, they remained unchanged for decades, apart from some minor formal changes which were included in the mid1960s (Ministério da Educação Nacional 1958a; 1958b; 1968). 
In most cases, a person read (or just touched) only one book during his/her lifetime, and its importance and influence was, of course, enormous. That single book was the textbook that the government had designed and approved for use in primary schools. Through it, the nation was taught a single world view, the sole ideology that the regime allowed, strictly categorised as being either good or evil. Children learned by heart, in a pre-established, perfectly organised and preordained manner. This form of teaching was even more effective as the messages were reinforced by clear, detailed and brightly coloured illustrations. Although this mode of education only remained in force until 1974, it still has a noticeable indirect influence nowadays. This is because former students are the teachers and parents of today, and they occasionally reproduce, often in a passive and non-critical way, the principles they learned in their childhood, principles that remain so attractive in their simplicity, as perfect guidelines for a world without doubts or choices. Thus, the ideology of Estado Novo successfully influenced-and still influences, under a thin cover of development-not only the cultural environment of the moliceiro, but also Portuguese culture in general.

Primary school textbooks placed their texts in rural settings, always within Portugal. Even when the text itself had nothing to do with the rural world, the accompanying image would establish a connection with the countryside. Any reference leading to praise of the transition from the countryside to an urban environment, or from agriculture to industry, was strategically and carefully avoided. Text and image were complemented with proverbs and traditional stories, representing oral knowledge and the collective memory of a peasant society, and by patriotic and religious symbols.

Eric Hobsbawm classifies the traditions invented after the Industrial Revolution into three categories: those that establish or symbolise social cohesion; those that establish or legitimate institutions, status or authorities; and those whose main purpose is the inculcation of ideas, systems of values and patterns of behaviour $(1983,17)$. These three categories are clearly present in the socio-cultural reality depicted in the Estado Novo textbooks, where history replaces mythology, although retaining the same function-according to Claude Lévi-Strauss $(1989,167)$. Children, guided by their teachers, as they learned to read, were also learning the official world order:

Estado Novo offered the Nation a new version of its past glory, (re)creating moments and characters according to the official interpretation of History, forging a new era, and restoring a mythical golden age that set the model for every celebration" (Paulo 1994, 91; my translation).

In destitute fishing and peasant communities like those of Ria de Aveiro, illiteracy was astonishingly high. For most fishermen, school was a mere bureaucratic formality, as only the minimum level of compulsory education was required in order to obtain a professional fishing licence. As far as the moliceiro community was concerned, crew, builders, and painters were either illiterate or barely able to sign their names when they applied for their licences, or registered their boat with the Port Authority. Because of this low level of literacy among the rural community, the sentences that caption the panels (always full of spelling mistakes) were traditionally painted by the few "literate" artists in the region. These artists acquired their meagre literary knowledge in primary school, and 
they constituted no exception to the rule that the primary school textbooks influenced their world view: such textbooks (as well as books in general) were rare treasures seldom found again after leaving school, and the power of their visual and verbal messages was irresistible.

Textbooks, therefore, exercised an obvious influence on the symbols and images popular painters chose to paint on the moliceiro panels, as can be proved by observing especially the Historical and Religious panels, particularly, those depicting historical characters such as king Dinis, the saintly knight Nuno Álvares Pereira, Henry the Navigator, Vasco da Gama, Pedro Álvares Cabral, and the poet Camões. All of these characters were portrayed in the textbooks in a similar solemn, static way, with different levels of accuracy and talent, but always following the same model. It is still easy to notice the influence of the image that illustrates the text "Camões" (in the fourth-year reader) on several Historical moliceiro panels depicting this famous Portuguese writer, who was adopted by the regime as the symbol of a glorious cultural tradition (Figure 3).

The glory, faith, ingenuity and wisdom of such historical characters is conveyed, in both panels and schoolbooks, through symbolic motifs such as a sword, flag, ship, castle, map, astrolabe, compass, or a book-the latter representing the national epic poem, Lusíadas, by the sixteenth-century Portuguese poet Luis Vaz de Camões. The Cross of the Order of Christ, the image on the sails of the ships from the Age of the Discoveries, is that which illustrated the cover of the fourthyear school reader. The Cross-omnipresent in Estado Novo iconography and,

(a)

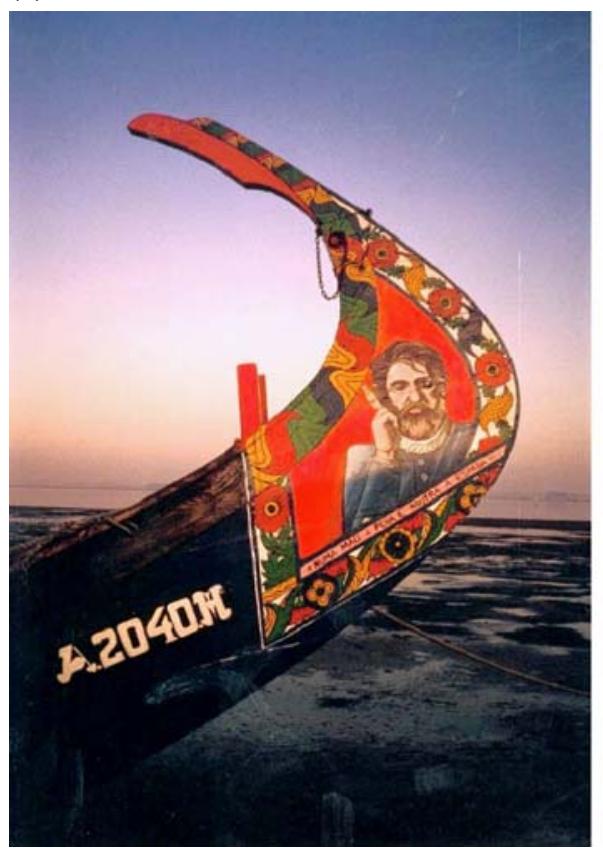

(b)

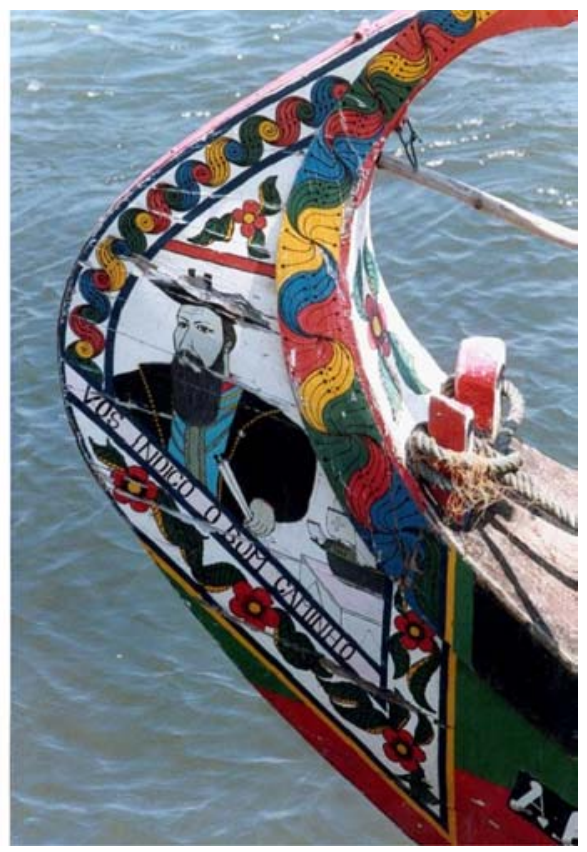

Figure 3. (a) Panel depicting the poet Camões (1990s). (b) Panel depicting the navigator Vasco da Gama (1990s). Photographs: Clara Sarmento. 
consequently, also to be found in textbooks (and even in the classroom as mentioned above)—was represented as the hero's companion and source of inspiration. This Holy Cross and the Portuguese flag appear in every category of panel except, as a sign of respect, comic ones.

Religious panels give preference to the protective maternal figures of the Virgin Mary, as well as Queen Saint Isabel, and the local Saint Joana of Aveiro, also because of the influence of textbooks. The reading selections in these books presented female characters, not as heroines but as companions of heroes, personifying Catholic virtues of resignation, faith, and charity. In general, therefore, women were associated with religion and Catholic virtues. Queen Saint Isabel and Saint Joana, were the subject of several texts, in which their sanctity and associated miracles were reported as true, unquestionable historical facts. The cult of the Virgin-strongly rooted in the Portuguese people-was carefully reinforced, not only in the reading section of the textbooks, but also throughout the long section entitled Christian (actually Catholic) Doctrine. These teachings were, and still are, reproduced and illustrated in many of the most skilfullydecorated Moliceiro panels (Figure 4).

Some moralistic texts were directly transferred from schoolbooks to the panels of the moliceiro, due to both their ideological impact and to the fact that painters actually agreed with the messages conveyed. The panel entitled "A good deed," for instance, depicting a young man carrying an old woman's bundle of wood, copies both the image and the title of the homonymous text, "A good deed," from the fourth-year reader, besides still inspiring other panels even as late as the 1980s (Figure 5(a)).

Similarly, the text entitled "Two Portuguese Boys" recalls the notion of "one great united Nation" ("Portugal extends from the Minho province to the province of Timor," because Portuguese colonies were thought of as mere overseas provinces, in order to avoid international criticism), which gave rise to panels declaring "Our blood is the same colour," "We're both children of God" (Figure 5(b)), and "Different in colour, but we share the same country," where different races worship the Cross and the Portuguese flag, as equals.

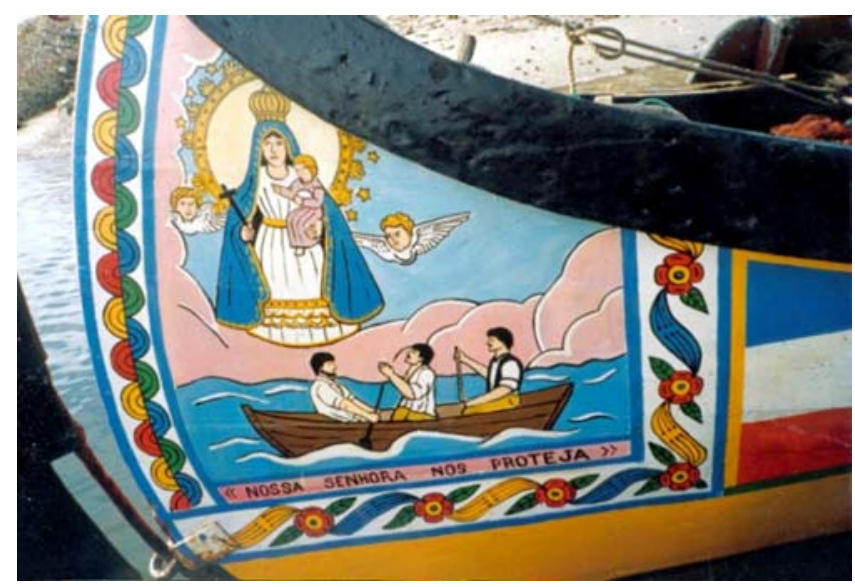

Figure 4. Panel depicting the Virgin Mary (late 1980s). Photograph: Clara Sarmento. 
(a)

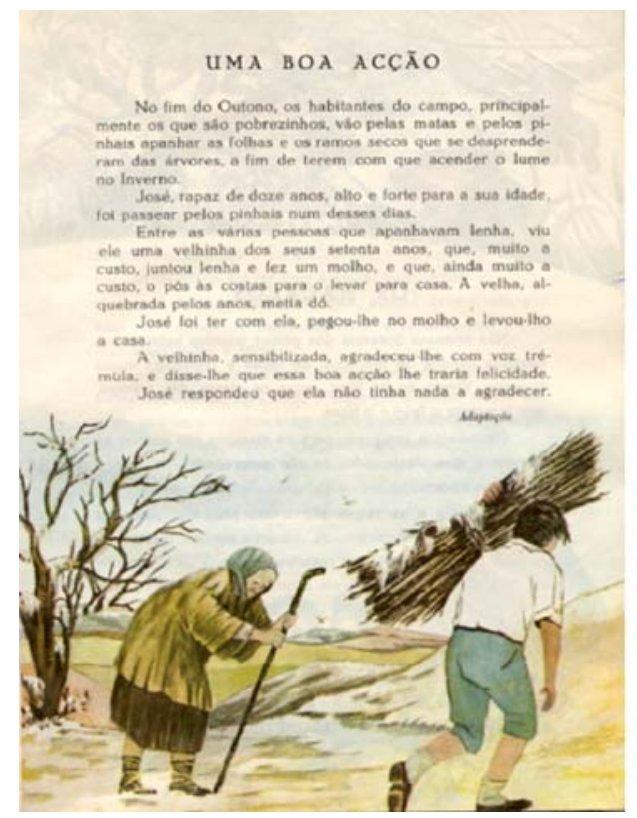

(b)

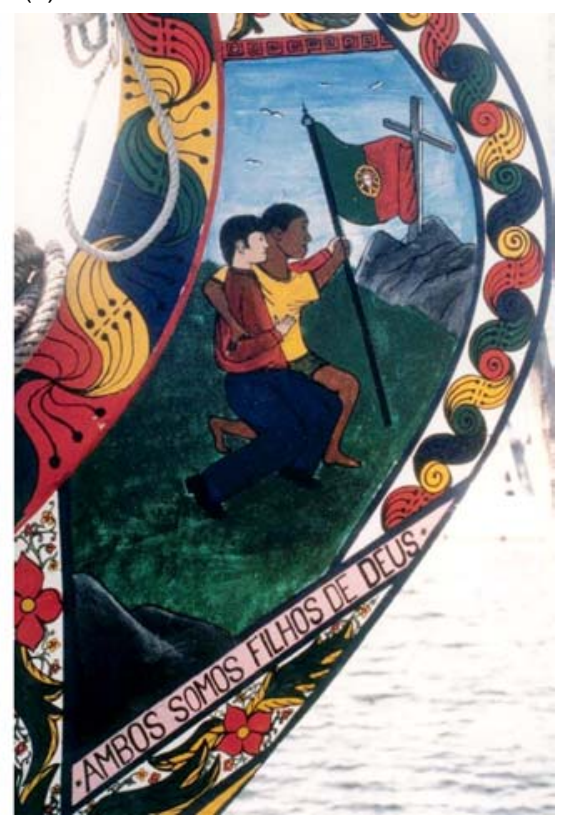

Figure 5. (a) "A good deed." Fourth-year textbook (1960s). (b) "We're both children of God" (1980s). Photographs: Clara Sarmento.

Although these ideological messages were conveyed in books aimed at children aged between the ages of seven and ten years, this does not mean that we should consider the art of the moliceiro to be a product of childish minds. Rather we should realise that painters simply retained, reproduced and, sometimes, adapted the few doctrines they had learned in primary school, and which the social, economic, cultural, and religious context of this historical period perpetuated in everyday life.

\section{Hidden Arts of Subversion}

Despite what has been said above, messages with dual meanings could be communicated under the cover of hegemony. Authorities were particularly attentive to, and actively supervised, this potential means of popular communication, and thus also of popular subversion. The moliceiro paintings were the main unauthorised and anonymous method by which the local people could express themselves, a fact that encouraged parody, and grotesque and subversive messages, as a counter-celebration of official values.

The anonymous moliceiro artists developed their own codes, myths, heroes, and social standards. Isolation, homogeneity of conditions, and mutual dependence among subordinates favoured the development of a local culture, often with a strong "us versus them" imagery. In subversive terms, once this occurs, the distinctive object itself becomes a powerful force for social unity, as all subsequent experiences are mediated by a shared way of looking at the world. The practical result is that popular culture-of which these panels form a part-achieves the anonymity of collective property, and is thus constantly adjusted, revised, 
abbreviated, or even ignored. The multiplicity of authors provides it with a protective cover, and when it no longer serves current interests sufficiently, it vanishes: thus panels are changed, repainted, rewritten or simply erased.

Moliceiro paintings tended to be seen as the product of a rude, simple, and naive local picturesque way of life. For almost a century, essays and ethnographies repeated these words when characterising moliceiro art, guided by cultural bias. Indeed, spelling mistakes, together with simple straightforward images in local settings, seemed to prove that they were, and are, the product of an ignorant, selfcentred community. However, social actors sometimes actually staged (and still stage) their own ignorance, thus creatively exploiting those stereotypes designed to depreciate and dominate them. Considered as ignorant by political and scientific authorities, and aware that any kind of direct criticism would be severely punished, painters would hide criticism behind the mask of ignorance in order to divert the authorities' attention. As Eric Hobsbawm stated: "the refusal to understand is a form of class struggle" $(1973,13)$.

Epic symbols, for instance, were not just reproduced but were also adapted to local heroes: the ship-builders and sailors who work within the sphere of the moliceiro are traditionally pictured on horseback, in a warrior-like attitude, often bearing a sword and a shield, and with a flag and a castle in the background. This is an original and subversive adaptation of the national saga to the local saga of common subsistence.

On the other hand, openly political texts such as "Estado Novo," "The Head of State," and "The Government of the Nation," a predictable presence in each year's schoolbooks, which praised Salazar's and his regime's virtues, had no influence on the moliceiro's writings and panels, although some ethnographies of that time tried to deny that fact (see Lage, Ferreira, and Chaves 1940, 72). [4] Ancient history, a remote past with its semi-legendary heroes, was celebrated by popular tradition as a rich, peaceful, golden age, just like the mythical past of kings, queens, knights and princesses of oral tradition. It was impossible, however, to celebrate contemporary mystified history, which the surrounding reality of poverty proved to be mere fiction. Moliceiros ignored political issues (even major issues, such as the colonial war); they did not criticise the authorities, but they did not praise them either. In fact, and to quote James C. Scott: "the distinctiveness of subordinate group cultural expression is created in large part by the fact that in this realm at least, the process of cultural selection is relatively democratic" $(1990,157)$. Subordinate groups select aspects that they choose to emphasise, they adopt them for their own use, and they thus create new cultural practices and artefacts to meet their needs and feelings. What survives, then, within popular culture is largely dependent on what the community decides to accept and transmit. This does not imply that cultural practices are unaffected by the dominant culture, but only that they are less effectively controlled by it.

Textbooks also taught children about the stereotypical image of women as mere mothers and housewives-a "noble mission" to which girls were introduced and which they had to accept since early childhood. According to the ruling ideology, women happily sacrificed their lives, working hard in the home, for their family, with children as their reward and major blessing. There is even a text in the second-year reading book where a thankful brother exclaims, in the last and eternal sentence: "How lovely are the girls who know needlework." Agriculture, 
in effect, was the sole non-domestic activity that the books allowed to, and celebrated for, women.

But in the real world of the moliceiro these stereotypes about women did not work exactly as the official representations and discourses had intended. In order to guarantee the family's subsistence, women had (and still have) to work extensively out-of-doors; thus housework and childcare were but small tasks in their long list of everyday chores. The women, as commonly depicted on the moliceiro panels, were, and are, peasants, fishmongers (varinas), fisherwomen (working on the beach and hauling the nets, an essential and very hard task in the traditional fishing process); they are, therefore, depicted as workers in their working environment, without any reference to childcare, housework, or even motherhood (except for the comic panels that satirise pregnant brides). The reading selections in the textbooks portray family scenes in a rural context, with clear hierarchies being symbolised through the height of the characters (men taller than women). Couples, as depicted in the moliceiro, however, are of a similar height and share the same functions, because both are equally active and relevant in everyday life (Figure 6).

Textbook readers and moliceiro panels traditionally shared a limited referential universe in time and space, one confined to small villages, rural environments, peasant communities, family, and everyday work. The notion that hard work in the open air was healthy and advantageous prevailed, although panels sometimes complained about the misery, difficulties, and dangers of work in the countryside, and at sea. The official image of the hard-working self-sacrificing peasant was celebrated in serious social panels about work, but it could be heavily satirised in comic panels as well. In a region so close to the sea, fishermen, instead of peasants, were celebrated in an almost epic manner. High-seas fishermen were never satirised, revealing an attitude very close to-although not motivated by-the rhetoric of the regime, which purported to represent such fishermen as the legitimate heirs of the heroes of the Age of the Discoveries-actually, this was just a mere rhetorical device as they lived in miserable conditions.

As a matter of fact, ideological supervision by central and local authorities was not totally effective. Painters satirised typical drunkards in the local pub (taberna)

(a)

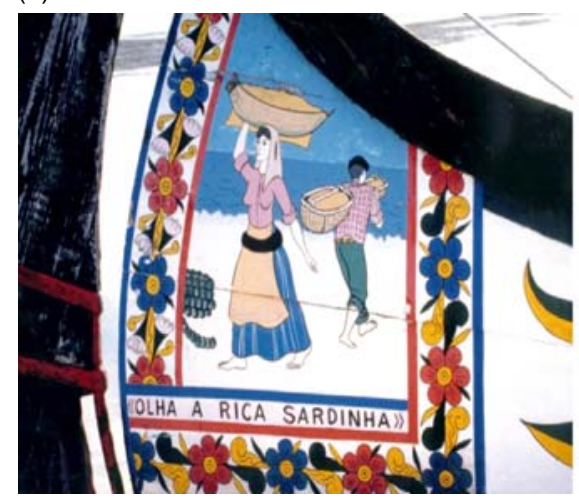

(b)

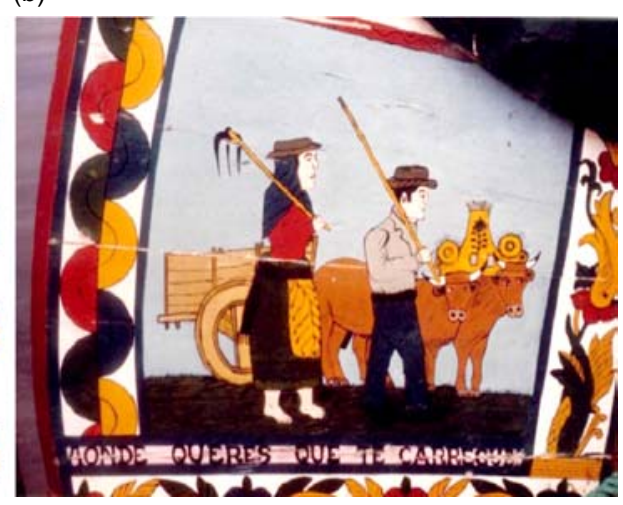

Figure 6. (a) Panel depicting fishmongers (late 1980s). (b) Image of a working couple and a satirical caption with sexual allusion (early 1980s). Photographs: Clara Sarmento. 
with a humour that exposed the comic side of reality, instead of following the institutional moralistic discourse. The taberna, the worst foe of the regime's moral code, was indeed a space for socialising, having been established by long social practice, and remaining immune to official rhetoric. But the specificity of the taberna in the Portuguese context needs to be considered: although the tabernatogether with Bakhtin's marketplace (Bakhtin 1984, 145-95) - is usually seen as a site of anti-hegemonic discourse (Scott 1990, 122), due to its relative insulation from surveillance, and to the fact that it was the main point of unauthorised assembly for lower-class neighbours and workers, it was not a space of organised, nor even of open, resistance, in pre-democratic Portugal.

The popular community only criticised the taberna when someone (men only) would spend his working hours and energy there, thus making him useless for work and the common good. Even so, the moliceiro's comments are always lighthearted and amusing, because reality actually balances good and evil, or allowed versus forbidden, patterns of behaviour, based on religious, national, and paternal authority ('God, Country and Family'), with rather pragmatic and flexible notes that have survived for decades.

\section{The Contemporary (Re)Invention of Tradition: Folklore as a Symbolic Commodity}

As traditional agriculture slowly disappears, the mental geography of the peasantmoliceiro community of Ria de Aveiro, is also changing-from a centuries-old agricultural space into a mere countryside landscape, where former spectators have also become actors. The massive diffusion of a tourism-oriented iconography of the Ria de Aveiro converts individual representations into collective ones, and these are aimed at dominant social groups. However, as in every polysemous message, there is a fragment of individual interpretation that survives, and that differentiates direct from indirect spectators, according to their cultural origin. Individual spectators are allowed to participate in a cultural, historical, social, and economic system. But their interpretation of the landscape, both real and figurative, must be consciously and critically inserted into a relationship that has been imposed on them by the fact that permanent residents have become part of the tertiary sector and are now in a minority in many areas of the Ria de Aveiro region.

Nowadays, popular culture and its production have to be increasingly attentive to the market and to the rules of demand and competitiveness-something that applies both to utilitarian and non-utilitarian productions. This process of refunctionalisation is controlled from afar by the demands of a heterogeneous mass of consumers who search for products that are vaguely symbolic of traditional Portugal. Without advocating support for the idea that "the fundamental elements of Portuguese culture" (Dias 1961, 97-119) are to be found in the "soul" of the objects conceived by the people, the handcrafted product is nonetheless in danger of becoming a commodity that, in many cases, can no longer be regarded as an expression of a community. The anonymity of the market, and the need to earn a living, can shape and transform the outlook of the artisans, as they shape and transform their own handcrafted pieces. In the case of the moliceiros, for example, there has been a clear rise in the number of comic erotic panels over the past two decades, the originality and easy humour of which 
greatly appeal to tourists. Until then, these subjects, although numerous, were traditionally in the minority, and also less explicit. The comic effect was usually the product of verbal innuendo. Nowadays, however, comic erotic panels are resorting to more and more unequivocal and elaborate images, and attract professional and amateur photographers who, in turn, disseminate their images to other potential visitors, and to the media, all of whom are sources of profit for the region (Figure 7).

When the market economy-which sustains the economic power that replaced hegemonic ideologies-does not understand culture itself, cultural heritage becomes externally determined and dependent on the images that others create and communicate. Thus, culturally shaped objects (such as the moliceiros) are transformed into consumer goods that, albeit acclaimed, are part of a commercial context that is removed from the reality that created them, and the possibility of understanding their function and meaning is lost.

The demand for genuine products may result in a staged authenticity, in which cultural objects purport to be produced and accepted as genuine, or at least as reasonably similar to the pre mass-culture situation. Hobsbawn considers that invented traditions are an attempt to create a continuous link with the past and with a community's identity $(1983,9)$. The concepts "traditional" and "authentic" are often linked together, an association that is not always correct, as the maintenance of authenticity is a cultural phenomenon that is directly connected to the process of continuity and change. Nonetheless, this staged authenticity may occasionally lead to the cultural rebirth of traditions, to the renewal of a local identity, and even to the invention of new traditions and identities.

(a)

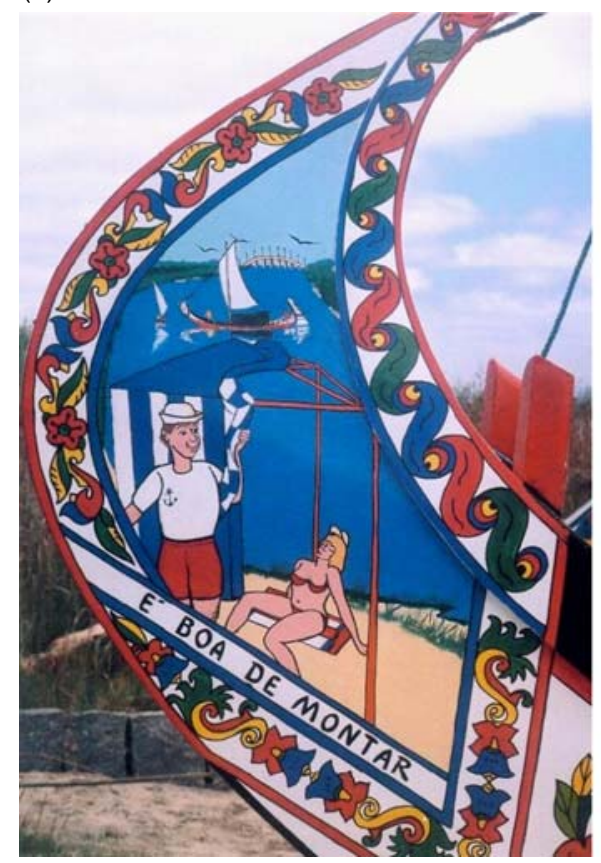

(b)

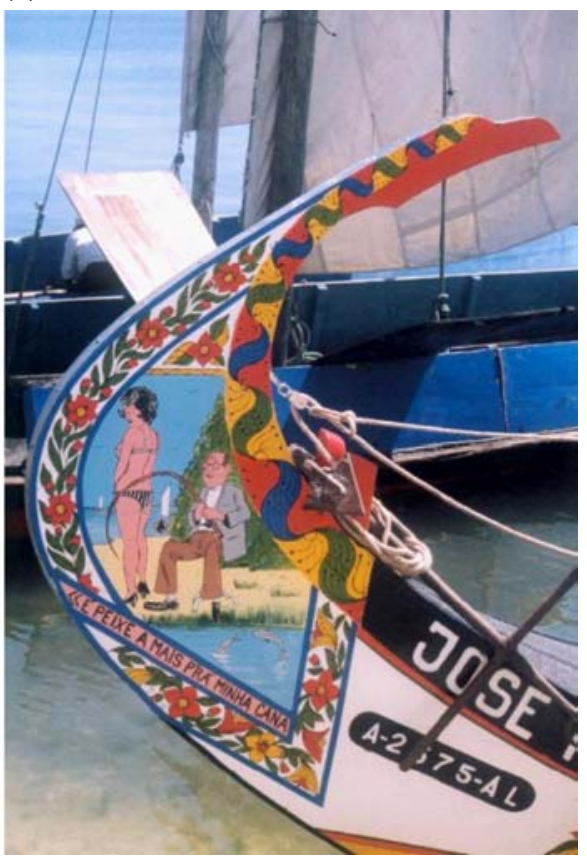

Figure 7. (a) Comic erotic panel (2002). (b) Comic erotic panel (2004). Photographs: Clara Sarmento. 
Once again, we take the example of festivals. The celebration of moliceiros and their paintings has never been a genuine popular practice. On the contrary, it is a recently invented tradition that is exploited, even today, by political and, especially, by economic and commercial powers, who artificially multiply reasons and occasions for such a profitable tourism-oriented celebration. At first, the boat owners themselves were very reluctant to participate in the festive competitions and they had to be threatened and bribed with consolation prizes in order to take part in the gaudy boat parade along the central canal in Aveiro. Nowadays, this attitude has changed considerably, as these monetary prizes are one of the few remaining means by which the owners of moliceiros can reap some profit from their boats.

In effect, the real importance of these events resides not so much in the strategy for preserving the marks of the past, but especially in recovering the more genuine aspect of the festival-that of a collective celebration in which everyone is potentially a leading actor. During the celebrations, regattas, and festivals, the roles become confused, and it is increasingly hard to distinguish tourists from locals, as the latter may behave like tourists on their own ground. Many of the people who stroll along the banks will have been directly or indirectly involved in building and painting the boats that are taking part in the festival, in a double process of exploiting the space for tourism. The interchange of codes and cultural practices, albeit only ephemeral, blur the frontiers that separate high culture from popular culture, in a desecration of the conventional criteria for aesthetic legitimacy.

(a)

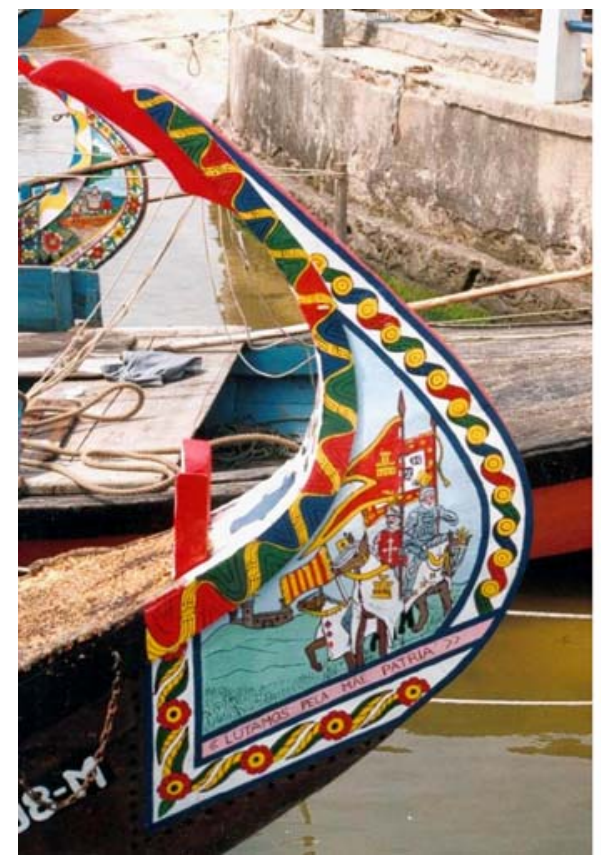

(b)

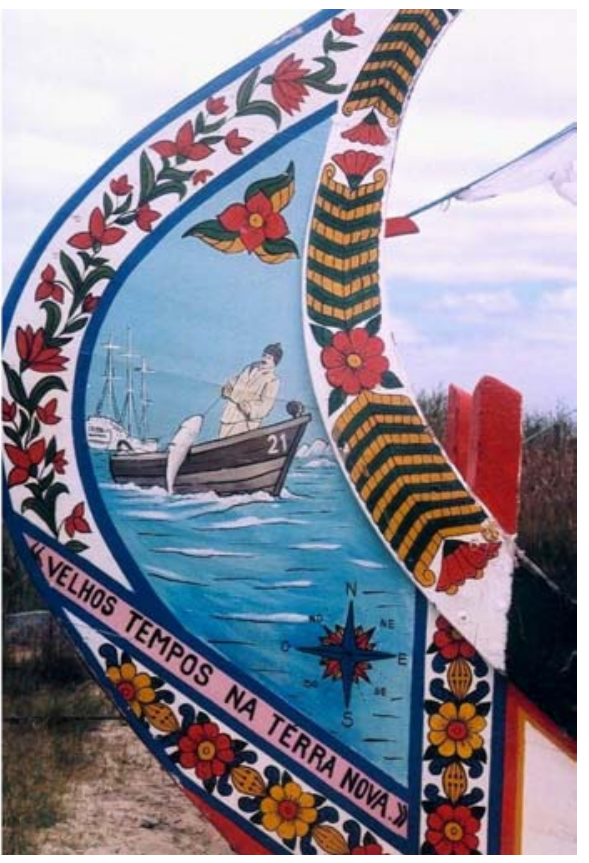

Figure 8. (a) "We fight for our motherland" (2002). (b) “Old times in Newfoundland" (1999). Photographs: Clara Sarmento. 
Nowadays, we cannot speak of a "rebirth" of the moliceiro boat, but rather of its "metamorphosis," as we have not returned to the living conditions of the past, nor has the seaweed, or moliço, which gave its name to the boat, any function in this new social context. The moliceiro reappeared in a fully democratic Portugal at the end of the 1980s, as a cultural object of interest to tourists, regardless of its original function. The moliceiro has been restored because of its elegant lines and unique adornments, just as any other boat might be restored if its aesthetic appearance justifies it. The moliceiro's metamorphosis occurs at the level of its function and meaning, as one element of an entire socio-economic structure, whilst retaining the object itself and its distinctive shape.

Generally speaking, in the ongoing recovery of the moliceiros for tourism, modern painters tend to imitate or even reproduce traditional images. They try to stage the past in the present. They exaggerate the traditionalism aspect as they reinvent tradition. The historical examples of great kings, warriors and navigators, along with the neo-epic celebration of high-seas fishermen, have survived, and are even represented in a higher proportion of craft nowadays, if we compare present panels with their counterparts of the 1950s and 1960s. Luis de Camões, the Estado Novo's national poet, for instance, is represented more often now than during the years when the regime was in power. During our field work, we found, among many others, the following examples of renewed traditional panels, whose captions and images still echo the ideology of the Estado Novo: "May God be your guide fishermen"; "We fight for our motherland" (soldier-knights); "The whole sea is ours!!" (Henry, The Navigator); "The pen and the sword in his hands" (Luis de Camões); "Old times in Newfoundland" (traditional cod-fishing) (Figure 8).

Present-day painters reproduce these ideologically-oriented symbols as if they were the remnants of some lost rural paradise, in an attempt to reinvent what they consider to be a picturesque, genuine, and popular part of the national Portuguese heritage. However, they do not quite comprehend-or, perhaps, they just pretend not to understand-that such images and messages are misplaced in time and space, as the surrounding ideological context has radically changed. Moreover, what was once seen as "genuine" was indeed what the State taught and allowed; it was by no means a trustworthy representation of reality.

Modern painters, some of whom have a secondary education or who are even graduates in Art, appear to set aside the modern artistic techniques that they master, as they try to create popular-like, but yet not popular paintings, in an attempt to obtain the prestigious (and, these days, also lucrative) social status of popular artists. Now, there is even a reputable female moliceiro painter, who is also a teacher of Visual Arts in a secondary school. The dialogue between the artist and his/her materials becomes not only a form of elevation, but also a rebellion against poverty, by turning a seemingly worthless object (a wooden boat meant to collect seaweed) into a delicate work of art. There is a considerable pecuniary reward for a generally recognised amateur talent, although nowadays these amateurs have already been engulfed by the tourism-oriented machine established around the moliceiro. In fact, the pressure to build new boats, and to renew the panels on time for the numerous summer festivals, as well as the tourists' preference for "perfect" drawings that do not require a complex interpretation, lead to a growing demand for new and skilled painters. Increasingly, less popular and more qualified, these new painters sometimes find it difficult to resist displaying their formal artistic skills. 
Women figure among the renewed subjects that have been introduced to modern moliceiro panels, where they are now depicted in a two-fold manner. The difference between the local woman (mother, wife, and always a countrywoman) and the "other" woman (the woman from the cinema and television, from the city; that is to say, the modern urban woman) is denoted by their clothing and functions. In the first case, work and working garments (headscarf, blouse, round skirt, apron, bare feet) are in evidence; while in the second case, leisure and leisure clothing (suggestive dresses, high heels, long hair, swimsuit or underwear) are presented. The varinas and fisherwomen continue to be strong, full of spirit and of quick retort, subservient to men in theory but powerful in practice-an inversion of the traditional social role that was assisted by the massive emigration of their men folk in the 1960s and 1970s. They function in an ongoing context of poverty and general hard work, and remain unmarked by stereotypical bourgeois behaviour. The "foreign" woman, on the other hand, is never included in laudatory panels such as those that praise varinas and fisherwomen; on the contrary, she is the object of extremely satirical paintings where she is mocked because of her sophistication and laziness. Such women are represented in their beds and boudoirs, lying on a couch watching television, sunbathing on the beach, or strolling around the spaces where others (the locals) work.

Still echoing the lessons from Estado Novo, modern (a traditional synonym for "immoral" during the Estado Novo period) young women are represented in erotic situations, where they are the object and the subject of sexual desire and sexual encounters, respectively. But, nowadays, women are actually men's peers when it comes to expressing their sexual intentions and awareness: in panels satirising condoms, for instance, women are the ones who actually instruct ignorant men on how to use them. When these young women are represented as varinas, rural workers and/or mothers, discourse may become poetical and laudatory, but parody still prevails in the moliceiro panels' representation of women, and includes witty remarks and comments full of sexual innuendo, in which women lead the way.

Symbols of work and production are also full of allusions to sex and procreation. This can be seen in the several metaphors in which women are referred to as fish, or as a good catch, and in the erotic paintings of women in a work context-such as fishing, hunting, gathering seaweed, or farming - that becomes one of pleasure. In humorous erotic panels, artists overemphasise the female body, depicting women in a carnavalesque manner, clothed in highlysuggestive, brightly-coloured, and, preferably red, garments.

In the panels depicting everyday life and work, a Bakhtinian carnavalisation (Bakhtin 1984, 4-11) is to be noted in the reversal of the roles of men and domestic animals. The donkey is frequently depicted with human characteristics-as a farmer, bad student, wise guy, and, especially, as a politician. There is also a reversal of roles and positions in the scene, as a man is shown carrying a donkey on his back, or pulling a cart, the reins of which are held by a donkey. In popular imagination, this reversal represents a more or less secret desire to also invert the social order of eternal poverty and domination. In the post-Estado Novo situation in Portugal, any resistance that may remain in moliceiro culture takes the form of heavy mockery, and is directed towards those authorities who, nowadays, make the once free and careless exploitation (that is, ruination) of the Ria's resources, so 
difficult, and-above all—towards the eternal scapegoats of democratic Portugal: politicians.

The police authority, for example, is always satirised. And so also are priests and monks because of their alleged luxury living disguised as virtue (a panel, where a girl in a red mini-dress attends confession, reads "Which one has sinned the most?"), although religion itself is never satirised under any circumstances. All professions are celebrated because all work is honourable; but all professions can also be themes for caricature, without malice-with the exception of the Master moliceiros, painters, or ship-builders, and high-seas fishermen because of the dangers they face. The only unworthy profession, the one whose actors are pictured as animals, is that of politicians. In this symbolic dispute, the winner is the voice of the people as expressed by the voice of the moliceiro through satire, criticism and complaint, thanks to the freedom of expression that has been guaranteed by democracy.

Bearing these examples in mind, it is easy to conclude that resistance (in the shape of satire) is much stronger in our time, and that it is aimed at the once almighty and revered agents of the church and of secular authority, as well as at the agents of a democratic regime that, ironically enough, released people from oppression and misery. The recently-acquired freedom of speech did not discipline the acid wit of moliceiro culture; the contrary is in fact the situation as is evident from the diverse representations of women, sex, politicians, clerics, and police officers, on the moliceiro panels.

One rarely finds panels that allude to middle-class life scenes: the panels depict the people/worker, based on their/his everyday activities, or royalty/nobility inspired by popular imagination. Nowadays, television is the great vehicle of social elevation and levelling, and its influence appears not only in some images (where television sets are actually represented) but also in the new characters and events that appear in the moliceiro panels-football players like Figo and Jardel; the diva of the fado Amália; "menino Tonecas," a childish character from a popular sitcom; politicians such as Mário Soares or António Guterres and the crisis and scandals they had to face; the feud between a mayor and the president of a local football team; the Portuguese entrance to the European Union in 1986, and the illusory prosperity of the 1990s on the basis of European funds; the single European currency, the Euro (whose earlier designation "Ecu" sounded like the slang form of "it is buttocks" in Portuguese); EXPO98, the celebrated universal exhibition in Lisbon; the notorious reality-show Big Brother; the national craze of the 2004 European Football Championship, as well as the 2006 World Football Cup; and the rivalry between local football teams, among many others themes and scenes. A reiterated or polemic news event-such as the illegal bullfights of Barrancos, in Alentejo, or the Brazilian nudist community of Colina do Sol-may rapidly generate a new panel for rapid consumption-and be rapidly replacedfor the sole reason that it has appeared on television.

All these events, subjects and characters, are democratically offered to people by television, an obligatory item in almost every household in modern Portugal $(99 \%$ of households, even among the poorest, had a television set according to the last Census report). Except for football-related examples, all other topics may be represented in an intentionally grotesque manner, and are subject to very satirical observations. Television merges images and words, just like a moliceiro panel, and 
thus becomes an irresistible source of inspiration for painters, especially when reality is no longer able to provide subject matters for scorn. As mentioned, football activities escape satirical presentation and comment, because the Portuguese football squad, as well as local football teams, are revered symbols, and are regarded as proud representatives of a nation, city, village or of a region's identity and are, therefore, portrayed accordingly. The national saga of the Age of the Discoveries, systematically celebrated by Estado Novo, has found in football a suitable, although unexpected, successor: both create an illusory sense of pride and divert attention from the actual situation of the country. By representing, commenting on, or satirising all of the above-mentioned topics, modern moliceiro culture illustrates, in a very lucid way, the unrestrained power of the media (Figure 9).

\section{Conclusion}

Popular culture can be used as an allegory and converted into a historical, ethnic, and ethical heritage, which allegedly belongs exclusively to an ambiguous character called "the people." In fact, from the onset, the concept of "popular culture" has laboured under a semantic ambiguity arising from the multiplicity of meanings that are couched in each of these two words; a polisemy that is equally evident whether they are applied singly or in concert. Popular cultures tend to be characterised as representing the mores of subordinate social groups, in defiance of subjugation. Popular culture, nonetheless, is more than a permanent and

(a)

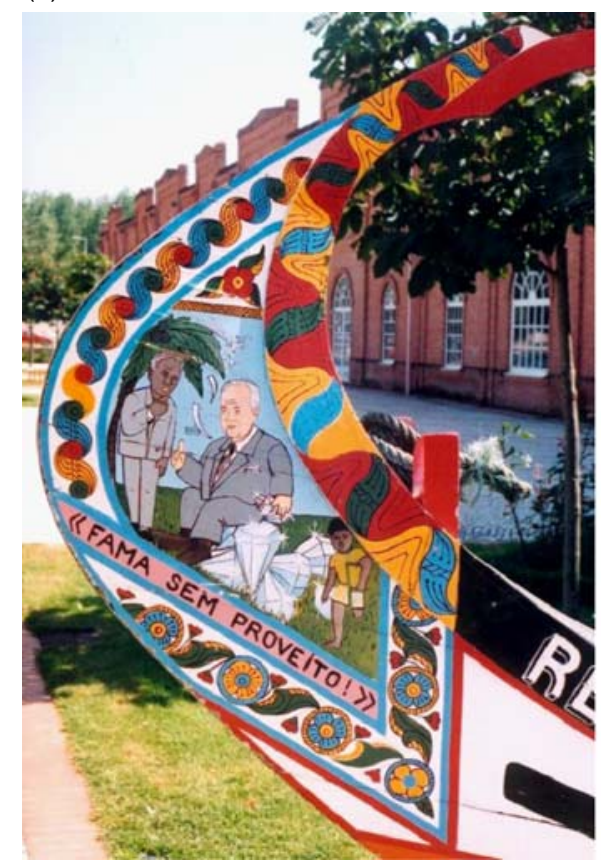

(b)

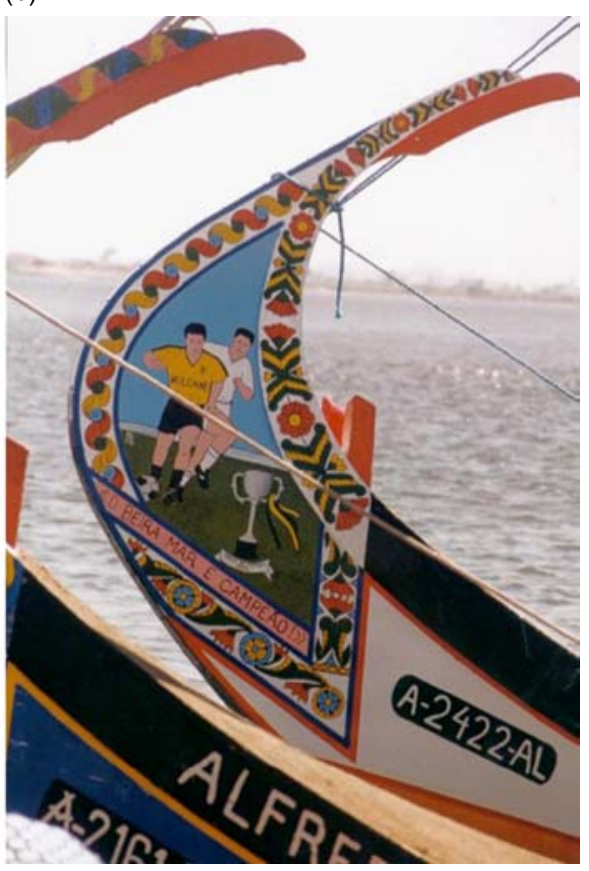

Figure 9. (a) Satirical allusion to an alleged scandal involving the former President Mário Soares (2000s).

(b) Celebration of the local football team Beira-Mar (late 1990s). Photographs: Clara Sarmento. 
systematic form of resistance, and can be defined as the various expressions of a social group's mode of coping with that dominance (Grignon and Passeron 1989).

Consequently, some objects of popular culture, such as the moliceiro boat and its panels, are rearticulated so as to produce oppositional meanings, thus creating forms of symbolic resistance. Popular culture is shaped by the dominant class's attempt at hegemony and by the forms of opposition to that attempt. This process of shaping popular culture does not consist simply of imposing a mass culture that agrees with the dominant ideology, nor of creating spontaneous oppositional cultures. This cultural process is, instead, a space of negotiation between bothwhere cultural and ideological values and features, both dominant and subordinate, mix and mingle in different exchanges.

Texts and images, such as those in the fascist-inspired schoolbooks we have analysed, exploited popular culture and ideologically-oriented truths, in order to establish the individual's position and immutable social role in the local and national territory. Yet, within the hegemonic discourses, we see resistance and acceptance, a fact that results in articulation; that is to say, in a negotiation between the dominant and the subordinate cultures, to use António Gramsci's terms. In his Prison Notebooks, Gramsci provides another essential clue for any serious and inclusive study of popular culture, when he affirms that "the starting-point of critical elaboration is the consciousness of what one really is, and is 'knowing thyself' as a product of the historical process to date which has deposited in you an infinity of traces, without leaving an inventory" (Gramsci 1971, 54).

This is precisely the lesson taught by the history of moliceiros-the written and iconic texts that are visible on each boat are the product of a network of political, ideological, social, and economical circumstances, which are hardly detectable and which are often too distant or taken for granted to be critically recognised, even by those who draw, paint, write, and live, under their influence. However, Gramsci's invisible "inventory" is the source of inspiration for traditional panels and allows them to be organised into categories, with a pre-established set of rules being tacitly followed for each one. In our time, new subject matter is continually added as a result of the volatile power of the media, although it is the popular artist-as a representative of the moliceiro community, who chooses which subjects should be discontinued and which should be reproduced and perpetuated.

The eager quest for the source of genuine Portuguese culture in the twentieth century inspired most of the pseudo-scientific discourse on the topic, a discourse that was intended to transform the description of popular traditions, into a description and justification of national identity itself. Therefore, this brief history of moliceiros also confirms that institutional channels of instruction and propaganda, official representations of reality, and documentary sources in general, must be carefully evaluated when studying the culture of a country that was dominated by censorship and by hegemonic powers for decades. Poetic and political devices were used to build and preserve the allegory of tradition as the guardian of true national identity, together with the myth of glorious origins that legitimated the self-proclaimed prestige of subsequent governments, as well as several other manipulated truths, which still are often repeated at the present time.

More than constituting evidence of "tradition" or "resistance," objects such as the moliceiro boat are now considered as representing the cultural identity and heritage of 
a local community, closely linked to a specific ecosystem such as the Ria de Aveiro. In the present case, the moliceiro panels are symbolic inter-semiotic representations of the values, practices, and representations, shared by the community. But nowadays the moliceiro paintings are also part of a lucrative economic and tourist structure organised around an object- the moliceiro boat. This object, however, has lost almost all of its former social and economic functions, and it has been reinvented as a nationally and internationally recognised cultural symbol for the Ria de Aveiro, one that clearly distinguishes the region from its competitors in other tourist areas. Once again, it is important to emphasise that what has occurred here is a metamorphosis, rather than the rebirth of a cultural object-the moliceiro craft that now has functions within a new context, functions that are clearly oriented towards the demand of the tertiary sector.

In conclusion, it can be stated that what has been studied in this article is a boat with unique characteristics that, initially, was strictly related to a community and to a local economy. Later, and throughout the entire twentieth century, the object in question participated in a dialectic between the representations of official discourse and its true social, economic, and symbolic functions. Nonetheless, present-day agents of tourism and the market economy cannot disassociate themselves from the historical imagery or from the inventory that motivated, contextualised, and sustained this form of popular culture over centuries, at the risk of creating, also in Portugal, the ethnographic theatres, or the museums of lost practices, into which so many cultures have been transformed.

\section{Notes}

[1] The Ria de Aveiro is forty-seven kilometres long and has a maximum width of seven kilometres, in spite of increasing silting. The depth varies between one and two metres and may rise to between four and six metres in the central canals. The Ria covers a liquid surface of more than six thousand hectares that divides into four main branches: Ovar (north), Mira (south), Murtosa (northeast) and Vagos (southeast). There is also an almost infinity of minor branches that create a large labyrinth of islands, channels, drains and creeks, across the entire area.

[2] However, the current financial crisis has forced local authorities not only to cancel or slowdown orders, but also to delay payment for many of them. During the optimistic year of 1998 (the year of Expo98), the municipality of Aveiro ordered something like twenty-five new moliceiros, but that project is currently suspended.

[3] Such as bathing the wooden image of a local patron saint (Saint Paio of Torreira) in red wine, in order to obtain protection against some common illnesses. That "holy" wine was consumed in great quantities afterwards, with predictable consequences.

[4] See the 1940 text by Luís de Pina, "Popular Art," in Francisco Lage's Vida e Arte do Povo Português ("Life and Art of Portuguese People"), published and supervised by the Secretary of National Propaganda, about the moliceiro panels: "But the artist updates his creations and, therefore, one can now find social and political allusions: busts of Salazar, legionnaires, members of the Portuguese Youth [the Mocidade Portuguesa, a fascist youth militia that every student had to belong to]. He updates and modernises his characters, group figures, and shows the influence of international politics" (Pina 1940, 69-81; my translation). However, the research undertaken for this study did not find one single representation of Salazar, legionnaires, or members of the Portuguese Mocidade (except for a sole and curious image that combines a boy dressed in the Portuguese Youth uniform with the portrait of king D. Manuel II, deposed in 1910), that would 
certainly have been the first images to be reproduced and publicised by the Secretary of National Propaganda, if they had actually existed.

\section{References Cited}

Bakhtin, Mikhail. Rabelais and His World. Bloomington: Indiana University Press, 1984.

Bourdieu, Pierre. Outline of a Theory of Practice. Translated by Richard Nice. Cambridge: Cambridge University Press, 1977.

Dias, Jorge. Ensaios Etnológicos [Ethnological Essays]. Lisbon: Junta de Investigação do Ultramar, Centro de Estudos Políticos e Sociais, 1961.

Gramsci, Antonio. Selections from the Prison Notebooks. Translated by Quintin Hoare. London: Lawrence and Wishart, 1971.

Grignon, Claude, and Jean-Claude Passeron. Le Savant et le Populaire: Misérabilisme et Populisme en Sociologie et en Littérature. Paris: Gallimard—Le Seuil, 1989.

Hobsbawm, Eric. "Peasants and Politics." Journal of Peasant Studies 1 (1973): 3-22.

Hobsbawm, Eric, and Terence Ranger, eds. The Invention of Tradition. Cambridge: Cambridge University Press, 1983.

Lage, Francisco and Paulo Ferreira, and Luis Chaves, eds. Vida e Arte do Povo Português [Life and Art of Portuguese People]. Lisbon: Secretariado da Propaganda Nacional, 1940.

Lévi-Strauss, Claude. Antropologia Estrutural. Translated by Chaim Samuel Katz and Eginardo Pires. Rio de Janeiro: Tempo Brasileiro, 1989.

Mattoso, José. História de Portugal [History of Portugal]. Vol. 7, O Estado Novo (1926-1974. Lisbon: Círculo de Leitores, 1994.

Ministério da Educação Nacional. Livro de Leitura da $3^{\underline{a}}$ Classe [Third Grade Reader]. Porto: Porto Editora, 1958a.

Ministério da Educação Nacional. O Livro da Primeira Classe [First Grade Reader]. Porto: Editora Educação Nacional, 1958b.

Ministério da Educação Nacional. Livro de Leitura para a 4⿳亠丷 Classe [Fourth Grade Reader]. Porto: Editora Educação Nacional, 1968.

Paulo, Heloísa. Estado Novo e Propaganda em Portugal e no Brasil: o SPN/SNI e o DIP [Estado Novo and Propaganda in Portugal and Brazil]. Coimbra: Minerva, 1994.

Pina, Luís de. "“'Arte Popular" ["Popular Art”]. In Arte do Povo Português [Life and Art of Portuguese People], eds. Francisco Lage, Paulo Ferreira, and Luis Chaves. 69-81. Lisbon: Secretariado da Propaganda Nacional, 1940.

Rivals, Claude. “"Peintures des Moliceiros d'Aveiro (Portugal): Culture et Arts Populaires” ["Paintings of the Moliceiros of Aveiro [Portugal]): Culture and Popular Crafts"]. Revue Géographique des Pyrénées et du Sud-Ouest tome 5, fasc 2-3 (1988): 247-72.

Scott, James C. Domination and the Arts of Resistance: Hidden Transcripts. London and New Haven: Yale University Press, 1990.

Silva, Augusto Santos. Tempos Cruzados: Um Estudo Interpretativo da Cultura Popular [Crossed Times: An Interpretive Study of Popular Culture]. Porto: Afrontamento, 1994.

\section{Biographical Note}

Clara Sarmento, Ph.D. in Portuguese Culture, develops her research on intercultural representations of gender, as the coordinator of the Centre for Intercultural Studies 
(www.iscap.ipp.pt/ cei) of the Polytechnic Institute of Oporto, where she is a tenured professor and the director of the master's Degree in Specialised Translation. She is the recipient of the American Club of Lisbon Award for Academic Merit and of the Portuguese Centre for Social Studies Award for Young Social Scientists. She is a former visiting scholar at Brown University, USA, and the author/editor of books such as: Women in the Portuguese Colonial Empire: The Theatre of Shadows (2008); As Palavras, a Página e o Livro: A Construção Literária na Obra de Paul Auster [The Word, The Page and the Book: Paul Auster's Literary Construction] (2001); Eastwards/Westwards: Which Direction for Gender Studies in the 21st Century (2007); and Cultura Popular Portuguesa: Práticas, Discursos e Representações [Portuguese Popular Culture: Practices, Discourses and Representations] (2008). 